\title{
Patent rights and economic growth: Evidence from cross-country panels of manufacturing industries
}

By Albert G.Z. Hu* and I.P.L. Png†

* National University of Singapore

† NUS Business School, National University of Singapore, 15 Kent Ridge Drive, Singapore 119245; e-mail: ipng@nus.edu.sg

\section{Abstract}

The objective of patent rights is to foster innovation and economic growth. However, to date, there is little robust evidence that patents achieve this objective. Here, we study the impact of changes in effective patent rights within panels of up to 54 manufacturing industries in up to 72 countries between 1981-2000. Stronger patent rights were associated with faster growth in more patent-intensive industries, and the effect was larger in higher-income countries. Between 1991-1995, an increase in the level of effective patent rights from Turkey to Singapore was associated with the average growth of the other chemicals and leather industries being respectively $1 / 6$ and 1/17 higher. Patent rights were associated with faster growth through both factor accumulation and raising productivity. Our findings were robust to alternative measures of patent rights and patent intensity.

JEL codes: O31, O34 


\section{Introduction}

In modern thinking on economic growth, a central tenet is that growth is endogenously sustained by technological change, which is a result of the conscious efforts of economic agents, lured by the monopoly rents that their innovations generate (Aghion and Howitt 1998: Chapters 2-3; Eaton and Kortum 1999; Barro and Sala-i-Martin 2004: Chapters 6-7; Zeira 2011). Unlike private goods, however, the use of innovation is non-rival and possibly nonexcludable, rendering it inherently susceptible to misappropriation. Thus, the incentive to innovate, and hence the rate of economic growth, depends on the extent to which innovators can reap the benefits from their creative efforts. An important institution that regulates the incentive to innovate is intellectual property (IP) rights.

The relationship between economic growth, innovation, and IP rights involves a tradeoff. Stronger IP rights raise the returns to innovation, but impede the diffusion of technology and subsequent innovations (Nordhaus 1969; Scherer 1972; Green and Scotchmer 1995). Thus whether strengthening IP rights leads to more or less innovation, and thus faster or slower economic growth is an empirical question. However, the empirical evidence on the effect of IP rights, particularly patent laws, on economic growth has been scarce and inconclusive (Hall 2007; Hu and Jaffe 2007). Indeed, Arora et al. (2008) concluded: “[S]tudies analyzing the impact of IPRs [IP rights] on innovation and growth have yielded mixed and, at times, difficult-to-interpret results.”

Despite the lack of empirical evidence, governments around the world continue to strengthen IP rights. In 1994, the Uruguay round of multi-lateral trade negotiations concluded with various agreements including the Agreement on Trade-Related Aspects of Intellectual Property Rights (TRIPS). In 2000, members of the World Intellectual Property Organization agreed the Patent Law Treaty. TRIPS reformed substantive law, while the Patent Law Treaty focused on harmonizing and streamlining procedures. Whether this wave of legal reforms has affected economic growth remains unproved and is the primary motivation of our research.

We focused on patents and investigated whether stronger patent rights have led to faster economic growth in an economically diverse sample of countries. Our empirical strategy exploited inter-industry differences in the importance of patents in protecting 
proprietary knowledge. As national patent rights strengthened, we asked whether more patent-intensive industries grew faster than less patent-intensive industries. For example, the pharmaceutical industry, which relies heavily on patent protection, might exhibit faster growth in response to stronger patent protection than the leather industry, where patents are less important. Another contribution of our study was to provide a measure of national patent protection that accounted for both the de jure coverage of patent laws and enforcement of the laws.

Using four panels of up to 54 three-digit ISIC manufacturing industries in up to 71 developed and developing countries, we found that stronger effective patent rights were associated with more patent intensive industries growing relatively faster, which effect was stronger in higher income economies. For instance, a one standard deviation increase in effective patent rights (equivalent to an increase from Turkey to Singapore) in 1990 was associated with the average annual growth of the leather industry being 1/18 higher, but that of other chemicals industry (which includes pharmaceuticals) being more than 1/6 higher in the following five years. Our findings were robust to extensive checks of specifications and measurement.

Our study contributes to the public policy discourse on the role of IP in economic growth and development. Patent rights do matter for economic growth. However, the impact of patent rights varies by country and industry. Patent rights have a smaller impact on economic growth in less patent-intensive industries and poorer countries. The optimal patent policy may well vary according to industrial structure and national income: “one size does not fit all”.

The rest of the paper is organized as follows. Section 2 reviews the previous literature. We set up the empirical model and discuss estimation issues in Section 3, and describe the sources of data and construction of variables in Section 4. Then, we report and discuss estimates of the baseline model and various robustness tests in Sections 5 and 6. Section 7 concludes.

\section{Previous Research}


Ginarte and Park (GP) (1997) compiled an index of patent laws for 60 countries between 1960-90. The GP index focused only on patent laws, as published, with no attention to actual enforcement. Park and Ginarte (1997) used the index to study the effect of patent laws on economic growth, investment, and R\&D expenditure. They found no relationship between stronger patent laws and economic growth. However, among richer countries (but not poorer countries), stronger patent laws were positively related to investment and R\&D.

Focusing on 18 manufacturing industries in OECD countries between 1980-95, Park (2003) found that both labor productivity and R\&D expenditure increased with the GP index. In a larger sample of countries, R\&D expenditure did increase with patent laws, but labor productivity did not. Among 32 countries between 1981-90, Kanwar and Evenson (2003) found that stronger patent laws, as measured by the GP index, were associated with higher R\&D intensity (ratio of R\&D expenditure to GDP). In panels of up to 72 countries over the period 1975-2003, a higher GP index was associated with higher R\&D intensity among highincome countries but not significantly related to economic growth (Kim, Lee, and Park 2008).

Two studies considered the relation between the national stock of patents (as contrasted with patent laws) and economic growth. In cross-sections of up to 86 countries in the year 2000, GDP per capita increased in the stock of patents, as instrumented by the GP index (Lederman and Saenz 2005). In a panel of 58 countries over 1980-2003, economic growth increased with R\&D expenditure and the stock of patents (Hasan and Tucci 2010).

For developing economies, a critical issue is whether stronger patent rights stimulate technology transfer by multinational corporations. Among foreign affiliates of U.S. multinational companies between 1982-99, royalty payments for intangible assets to parent companies, R\&D expenditure, and patenting increased with patent reforms in the host country (Branstetter et al. 2006). Further, in a sub-sample of 16 countries, the patent reforms led to an increase in industry-level value added, suggesting that reductions in value-added associated with imitation were outweighed by increases in value-added due to technology transfer by multinational companies (Branstetter et al. 2011). By contrast, Kanwar (2012) found no relation between IP protection and location of R\&D investment by U.S. multinationals between 1977-2004. 
In independent work closest to ours, Vichyanond (2009) studied the impact of patent laws, represented by the GP index, on manufacturing exports. He regressed exports by industry-country on the interaction between the GP index and patent intensity (with patent intensity being the number of U.S. patents weighted by citations divided by the average value of U.S. production). The impact of patent laws was non-monotone: Below a threshold, exports increased with stronger patent laws, while beyond the threshold, exports fell with stronger patent laws.

Several studies have focused on the impact of patent laws on innovative activity, as distinct from economic growth. Among 26 countries that expanded the scope of patent law to pharmaceuticals between 1978-2002, stronger patent protection was associated with higher domestic R\&D only among economically advanced countries (Qian 2007). Moser (2005) studied innovations exhibited at 19th century World Fairs. Countries without patent laws focused innovations on industries where patents were less important, suggesting that patent laws significant affected the direction of technological innovation. Among 15 Western countries over several centuries, enactment of patent law was associated with higher rates of scientific discoveries, inventions, and innovations (Chen 2008).

Among previous cross-country analyses, only Branstetter et al. (2011), focusing on developing countries, found strong results linking patent laws to economic growth. The relatively limited results from the other studies might possibly be explained by the aggregate nature of the investigation. Intuitively, the impact of patent laws might vary with the industry, and would be attenuated in aggregate, country-level analyses.

\section{Empirical Strategy}

To investigate whether stronger patent rights promoted economic growth, we specified the following empirical model:

$$
\begin{aligned}
\Delta \log \left(V A_{i c}\right)= & \alpha_{0}+\alpha_{1} \log \left(V A_{i c, 0}\right)+\alpha_{2} \text { Effective Patent Rights }_{c, 0} \times \text { Patent Intensity }_{i} \\
& +\beta_{c} D_{c}+\beta_{i} D_{i}+\varepsilon_{i c},
\end{aligned}
$$

where the dependent variable, $\Delta \log \left(V A_{i c}\right)=\Delta V A_{i c} / V A_{i c}$, was the growth of value added over a five-year period for industry $i$ in country $c$. Effective Patent Rights $s_{c, 0}$ represented the strength of the country's patent rights at the beginning of the period; Patent Intensity ${ }_{i}$ 
characterized the importance of patents to industry $i$ in appropriating the returns from innovations, and $D_{c}$ and $D_{i}$ were country and industry fixed effects. We also included the initial level of value added, $\log \left(V A_{i c, 0}\right)$, as a control for time-invariant industry-country characteristics that might be correlated with the interaction of effective patent rights and patent intensity. $^{12}$

In the spirit of Rajan and Zingales (1998), the identification of the impact of effective patent rights on economic growth as specified in eq. (1) drew on variation in effective patent rights across countries and the assumption that the impact varied across industries within a country. By exploiting industry-country variation in industry growth, we could control for both country- and industry- specific effects. This identification strategy distinguished our study from the previous literature.

Our primary interest was in the coefficient of the interaction between patent rights and patent intensity, $\alpha_{2}>0$. More specifically, we investigated whether and to what extent more patent-intensive industries grew relatively faster in response to stronger effective patent rights in the country.

We emphasize that stronger effective patent rights, by providing inventors with greater exclusivity, need not necessarily imply faster industry growth. Among advanced economies, stronger effective patent rights could stimulate the prospective invention of new products and processes, but, by limiting the usage of existing inventions, would reduce usage and follow-on invention (Green and Scotchmer 1995; Bessen and Maskin 2009). Among developing economies, stronger effective patent rights would reduce imitation and free-riding

\footnotetext{
${ }^{1}$ Since our specification included country and industry fixed effects, we could not include patent intensity (which varied with industry but not country) or effective patent rights (which varied with country but not industry) as separate explanatory variables, since these would not be identified.

${ }^{2}$ We did not pool the data from the four periods into a single industry-country-year panel because the industry mix in the countries varied substantially over time. To cope with this variation, it would be necessary to include separate country fixed effects for each time period, which would be equivalent to our procedure of estimating separate industry-country panels for each of the four periods.
} 
on the technology of advanced economies, but might stimulate technology transfer by multinational companies. ${ }^{3}$

We should note that our identification strategy did depend on the assumption that country-industry specific shocks were not correlated with the choice of effective patent rights at the national level. In particular, it might be possible that, in countries where patentintensive industries were growing relatively faster, these industries would lobby for stronger effective patent rights. We addressed this concern by specifying effective patent rights as at the beginning of each period, which would precede any industry specific shocks during the period. Further, in a robustness check, we applied instrumental variables estimation, using measures of legal origin that have been widely used as deep determinants of national institutions.

Our identification strategy also depended on the assumption that the relative patent intensity of industries was the same across all countries. While eq. (1) specified patent intensity as varying by industry only, the specification could accommodate an additive country-specific element in patent intensity which is common to all industries in the country. In any estimation, this country-specific element would be absorbed by the country fixed effects. Hence, our assumption reduced to assuming that the relative patent intensity across industries was the same in all countries.

\section{Data and measurement issues}

\subsection{Industry value added}

We used the World Bank Trade, Production and Protection (TPP) database (Nicita and Olarreaga 2007) to compile data on the value added, employment, and gross capital formation by 3-digit manufacturing industry (ISIC (International Standard Industrial

\footnotetext{
3 It might be asked why national patent laws should matter at all. One possible view is that only the patent laws of major world markets should matter, with the location of production being determined by comparative advantage. For instance, if China produces electronics only for the U.S. market, then only U.S. patents should be relevant. However, this reasoning ignores patents that protect processes. If China does not enforce patents on processes, an interloper might copy a manufacturer's processes, and produce in China and then export similar (but not infringing) products to the U.S.
} 
Classification, rev. 3), 151-372) for up to 72 countries between 1976-2000. ${ }^{4}$ The World Bank TPP database provided varying coverage by country and year. It was particularly limited beyond the year 2000, covering just two years for many countries. Accordingly, we ended the period of study in 2000. We deflated the industry value added by the corresponding U.S. value added deflator. In the absence of a more appropriate deflator for capital goods, we also deflated gross capital formation by the value added deflator.

\subsection{Effective patent rights}

A major challenge was to quantify the strength of the national patent regime in each country so that we could track changes over time and compare across countries. Previous studies used the GP index compiled by Ginarte and Park (1997) and updated by Park (2008). The GP index assigned each country a score between 0 and 1 for each of five elements: the extent of coverage of patent protection, membership in international patent agreements, provisions for protection against loss, enforcement mechanisms, and duration of protection. The GP index was the unweighted sum of these individual scores and ranges from 0 to 5 . The index covered up to 119 countries at five-year intervals from 1960 to 2005.

In essence, the GP index measured the completeness of laws de jure. For instance, it measured enforcement only to the extent that the legal system provides for preliminary injunctions, pleadings of contributory infringement, and reversal of the burden of proof. The GP index did not measure actual state of patent rights, de facto. For instance, among developing countries, the 1990 index rated Malawi (3.24) and Nigeria (3.05) ahead of Hong Kong (2.57) and Singapore (2.57).

To our knowledge, no systematic, cross-country metric of enforcement of patent rights is available for our period of study. The closest is the Fraser Institute's index of legal system and property rights, which was reported on a scale of 0 to 10 for up to 141 countries at 5-year intervals from 1970-2000. From 1980 onward, the index was compiled from subjective measures of three aspects of the legal system and property rights: legal security of private ownership rights (risk of confiscation); viability of contracts (risk of government repudiation of contract); and rule of law (Gwartney et al. 2000). These subjective measures

\footnotetext{
${ }^{4}$ The original source of the data was an annual survey by the United Nations Industrial Development Organization (Yamada 2005).
} 
were compiled from surveys of international business executives as published in the International Country Risk Guide.

Drawing on the GP and Fraser indexes, we propose a new index of effective patent rights that accounts for both the state of patent laws and their enforcement. The new index is the product of the GP and Fraser indexes:

Effective patent rights index $=$ GP index $x$ Fraser index .

Generally, laws and enforcement are complements (Becker 1968; Mookherjee and Png 1992). For an innovator, a situation of complete patent laws with zero enforcement seems little different from a situation of no patent laws at all. Two elements of the GP index measure the scope of the patent law. The score for coverage ranges from 0 to 1 depending on the number of product categories that are patented. Any increase in enforcement would raise protection on all of the products covered. Similarly, any increase in enforcement would generally enhance loss protection. Accordingly, it seemed reasonable to construct the index of effective patent rights as the product of the GP and Fraser indexes.

Our index of effective patent rights depended on an assumption that enforcement of patent rights was correlated with enforcement of property rights in general, as measured by the Fraser index. While this crude approximation was necessitated by the limited data, we could not think of strong reasons or systematic evidence against it.

As Fig. 1 shows, the Fraser index and GP index were correlated. ${ }^{5}$ Further, the correlation between the two indices appeared to be stronger among OECD countries than non-OECD countries. ${ }^{6}$ Towards the end of the sample, the correspondence between the two indices tended to converge among OECD and non-OECD countries. Apparently, the published law was much better enforced in economically advanced countries than in developing countries, but, over time, the disparity has narrowed. Fig. 1 also depicts a 45

\footnotetext{
5 The Fraser index was produced on a 10-point scale, while the GP was on a 5-point scale. Accordingly, for easier visualization in Fig. 1, we scaled up the GP index by a factor of 2 .

${ }^{6}$ For the years 1980, 1985, 1990 and 1995 respectively, the correlation coefficients were: (i) OECD: 0.91, 0.90, 0.93 and 0.84; (ii) non-OECD: 0.59, 0.65, 0.59 and 0.81.
} 
degree line. Relatively more non-OECD countries fell below the line, which indicated that, in these countries, enforcement lagged formal patent law.

[Insert Figure 1 here]

Table 1 presents the top and bottom five countries by the effective patent rights index. The U.S. ranked highest throughout, the Netherlands always placed among the top five countries, while Jordan was consistently among the bottom five.

[Insert Table 1 here]

To further appreciate the cross-country pattern of effective patent rights, we analyzed the variation of the index into three components: between OECD and non-OECD, within OECD, and within non-OECD. As Fig. 2 shows, the variation within OECD and non-OECD countries, was dominated by that between the two groups, which consistently accounted for over $60 \%$ of the total variation. Further, the variation in the index shrunk towards the end of the sample.

\section{[Insert Figure 2 here]}

In our main specification, the index of effective patent rights was constructed as the product of the GP and Fraser indexes. In robustness checks, we used two alternative constructions of effective patent rights. One was the geometric mean:

$$
\text { Effective patent rights index }=(\text { GP index } x \text { Fraser index })^{1 / 2 .}
$$

This construction was also premised on complementarity between patent law and enforcement, but with constant returns to scale. The other alternative was constructed as an average, based on the premise that law and enforcement were independent,

$$
\text { Effective patent rights index }=[\text { GP index }+0.5 \times \text { Fraser index }] .
$$

Since the GP index ranged from 0 to 5 , while the Fraser index ranged from 0 to 10 , we divided the Fraser index by 2 in order to give equal weight to patent laws and their enforcement. The rankings of countries by our main and alternative indexes of effective patent rights were quite similar. 


\subsection{Patent intensity}

For each industry, we measured patent intensity by the ratio of the number of patents awarded to an industry to the total sales of the industry. We used U.S. data to construct this measure of patent intensity and assumed that this measure reflected the relative patent intensity across industries in all other countries.

Using Compustat, we extracted the sales of individual companies by 3-digit ISIC, aggregated by industry, and then deflated by the value added deflator, in the absence of an appropriate industry sales deflator. ${ }^{7}$ We then used the NBER Patent Database (Hall, Jaffe, and Trajtenberg 2001) and the link through the Compustat identification numbers to identify the U.S. patents granted, and aggregated the numbers of patents to the same 3-digit ISIC level. Finally, we computed patent intensity for each industry as the ratio of aggregate industry patent grants to total deflated industry sales over the period, 1979-2000. ${ }^{8}$

The Appendix presents the average patent intensities for various industries. The measure seemed to be intuitively reasonable: the patent intensity of ISIC 242 (Other chemicals) was 0.0240, an order of magnitude larger than that of ISIC 15 (Food and beverages), which was 0.0012 . The patent intensity of ISIC 30 (Office, accounting, computing machinery) was 0.0513 , as compared with 0.0072 for ISIC 21 (Paper products). To avoid any bias due to the use of U.S. data to calculate patent intensity, we excluded the United States from all estimates.

The various countries differed in their mix of industries, and this mix varied over time. Fig. 3 depicts patent intensity (weighted by industry shares of national value added) and effective patent rights by country. Interestingly, countries that were dominated by patent intensive industries tended to have stronger effective patent rights. This correlation did not pose any challenge to our empirical strategy, which was to test whether more patent-intensive

\footnotetext{
${ }^{7}$ Compustat identified industries by North America Industry Classification System (NAICS). We mapped ISIC to NAICS using the U.S. Census Bureau concordance: http://www.census.gov/epcd/naics/concordances/index.html.

${ }^{8}$ Compustat covers only publicly-listed U.S. companies. Our procedure omitted patents granted to companies which were not U.S. publicly-listed. However, the numerator and denominator in our measure of patent intensity were consistent in the sense that both pertained to the same set of listed U.S. companies. Our procedure successfully matched at least $26 \%$ of patents issued to U.S. manufacturers between 1979-2000.
} 
industries grew relatively faster in countries with stronger effective patent rights, as distinct from the question of whether more patent-intensive industries were larger in countries with stronger patent rights.

[Insert Figure 3 here]

In robustness tests, we applied several alternatives to the patent intensity measure. One was the industry ratio of patent applications to sales. Another was the ratio of R\&D to sales over the period 1979-2000, computed from Compustat as the ratio of R\&D to sales for each industry.

For the third alternative, we compiled data from China, specifically, all invention patents granted by the State Intellectual Property Office (SIPO) and sales from the industrial census, to calculate the patent intensity between 1998-2004. Compared with the U.S. patent intensity, the industry coverage was more limited, and the two differed in the scale of the denominator (being measured in U.S. dollars and Chinese Yuan respectively). Nevertheless, the two benchmarks were quite similar in their characterization of industry patent intensities: the null that the two benchmarks were independent was rejected at the $1 \%$ level.

\subsection{Other data and measurement issues}

In one exploration, we investigated the impact of effective patent rights on total factor productivity. We drew on the World Bank TPP database and applied the perpetual inventory model to construct capital stock, assuming 5\% annual investment growth and 10\% annual depreciation. We then estimated an industry production function and growth of total factor productivity.

Finally, the combination of the coverage of the World Bank TPP database (essentially up to 2000) and effective patent rights index (5-yearly from 1980) limited our analysis to four 5-year intervals, viz., 1981-85, 1986-90, 1991-95, and 1996-2000. For each 5-year period, we regressed the growth of the logarithm of value added by industry on the interaction of the effective patent rights index in the year preceding the interval and the industry patent intensity. For instance, we regressed the growth of the logarithm of value added between 1981-85 on the interaction of the effective patent rights index in 1980 and the industry patent intensity. Table 2 summarizes the data used in our analysis. 
[Insert Table 2 here]

\section{Results}

Table 3, Panel A, presents least squares estimates of the baseline specification, eq. (1). The coefficient of the interaction between national effective patent rights and industry patent intensity was positive in all periods and statistically significant in the later periods 1991-95 and 1996-2000, and marginally significant in the earlier periods. ${ }^{9}$ The model also included the initial value added (value added at the beginning of the period) as a control for countryindustry heterogeneity. In all four periods, the coefficient of the initial value added was negative, implying that smaller industries were catching up with bigger ones. The model fit the data reasonably well, explaining between $46-58 \%$ of the variation in industry growth. ${ }^{10}$

\section{[Insert Table 3 here]}

For comparison, Table 3, Panel B, reports estimates of the baseline specification, (1), on a balanced panel limited to the same countries and industries in all time periods. The different composition of the unbalanced and balanced panels was mainly due to variations in the coverage of the GP index. The balanced panel contained relatively more OECD countries and fewer developing countries, and was up to $40 \%$ smaller, so, reducing the power of the estimates. Nevertheless, the results regarding the impact of effective patent rights were similar to those based on all available countries and industries. However, there was less evidence of convergence: the coefficient of the initial value added was negative and significant only in the period 1986-90.

From the balanced panel estimates, it was evident that patent rights grew in economic (and statistical) significance over time. Notably, the impact of patent rights appeared to be stronger between 1991-95, when the Uruguay round of trade negotiations, including the TRIPS agreement, were concluded, and even stronger between 1996-2000, when the TRIPS

\footnotetext{
${ }^{9}$ In all of the estimates, we excluded five outliers - one for Thailand (THA) in 1986-1990, one for Nigeria (NGA) in 1991-95, and three for Algeria (DZA) in 1996-2000.

${ }^{10}$ In each regression, the dependent variable was the average of the growth of the logarithm of industry value added over the 5-year period and the sub-sample comprised one observation per industry-country for the 5-year period. Hence, each "industry-country" cluster was a singleton. We checked and obtained similar results with standard errors clustered by country.
} 
agreement came into effect. The increasing trend in the impact of patent rights was also possibly related to overall economic growth. As we discuss below (in Table 5), the effect of patent rights on industry growth increased with national income. So, by raising national income, overall economic growth would lead to a stronger relation between patent rights and industry growth. ${ }^{11}$

To appreciate the economic significance of our results, we carried out counterfactual policy experiments using the estimates from the entire data set (Table 3, Panel A). In 1990, for an industry with the overall average patent intensity of 0.018 , an increase in effective patent rights by one standard deviation, 9.4, or approximately the equivalent of increasing protection from the level of Turkey (5.37) to Singapore (14.79), would have contributed to an increase of the growth rate of value added by $0.0442 \times 0.018 \times 9.4=0.75 \%$ points. Compared with the average industry growth rate of 3.6\% in 1991-1995, the effect of strengthening patent rights on economic growth was substantial in economic terms.

\section{[Insert Table 4 here]}

Table 4 presents counterfactuals with respect to the effect of a one standard deviation increase in effective patent rights on the growth rate for each industry during the respective time period. Evidently, the impact was larger among more patent-intensive industries, such as office, accounting, and computing machinery (ISIC 30, patent intensity 0.0513 ) as compared with less patent-intensive industries, such as wood products (ISIC 20, patent intensity 0.025 ) and other chemicals (ISIC 242, patent intensity 0.024) as compared with even less patent-intensive industries, such as leather (ISIC 19, patent intensity 0.0105). In the 1991-95 period, a one standard deviation, 9.4, increase in effective patent rights was associated with the annual growth rate of the leather industry being $0.47 \%$ higher, or about one seventeenth of the industry's average growth rate of $8.18 \%$, and that of other chemicals being $1.07 \%$ higher or more than one sixth of the average growth rate of $5.9 \%$.

\footnotetext{
${ }^{11}$ Yet another possible explanation for the increasing trend in the magnitude and significance of the estimated effect of effective patent rights is measurement error. Patenting tended to increase over time across all industries in all countries. Hence, any measurement error in using the U.S. patent intensity as a benchmark was more serious in the earlier periods. Thus, in the earlier periods, the estimates would be subject to greater attenuation, and so, the estimated coefficients would be smaller and standard errors higher.
} 


\subsection{Level of economic development}

Previous research (Park and Ginarte 1997; Kim, Lee, and Park 2008; Branstetter et al. 2011) found that the impact of patent laws varied with national economic development. To explore whether the same was true in our data-set, we estimated a revised specification with growth of industry value-added regressed on the interaction of industry patent intensity, national effective patent rights, and GDP per capita. ${ }^{12}$

\section{[Insert Table 5 here]}

As reported in Table 5, the coefficient of the interaction was positive and statistically significant in all periods. As with the main estimates, the impact of patent rights appeared to be stronger in the 1990s than in the 1980s. These results suggested that the impact of patent rights on economic growth was stronger in more economically advanced countries, and, that the impact strengthened with overall economic growth. The results provide an explanation of the increasing trend in the impact of effective patent rights on industry growth reported in Table 3 above.

\subsection{Factor accumulation and productivity growth}

Stronger patent rights would increase the returns to innovation. The higher returns might stimulate more R\&D and higher growth of productivity. The higher returns might also stimulate increased inputs of capital services and labor. Hence, the growth-promoting effect of patent rights that we have identified encompassed the contribution of both higher productivity growth and factor accumulation. To distinguish these effects, we estimated a Cobb-Douglas model, for industry $i$ in country $c$,

$$
\begin{aligned}
\Delta \log \left(V A_{i c}\right) & =\alpha_{0}+\alpha_{2} \text { Effective Patent Rights }_{c, 0} \times \text { Patent Intensity }_{i}+\alpha_{3} \Delta \log K_{i c} \\
& +\alpha_{4} \Delta \log L_{i c}+\beta_{c} D_{c}+\beta_{i} D_{i}+\varepsilon_{i c}
\end{aligned}
$$

\footnotetext{
${ }^{12}$ The double difference (effective patent rights x patent intensity) and triple difference (effective patent rights x patent intensity x GDP per capita) were almost perfectly correlated. So, any regression including both double and triple differences was plagued by multi-collinearity. To avoid this problem, we included only the triple difference. The only substantive consequence was that this specification forced the coefficient of the double difference to be zero for countries with zero ln GDP per capita, which was merely a matter of measurement scale.
} 
where $K_{i c}$ represented capital services and $L_{i c}$ represented labour input. This specification assumed that the interaction of effective patent rights and patent intensity affected only the growth of total factor productivity (TFP).

Owing to limited data on capital and labour, the sample size was reduced by up to half, so reducing the power of the statistical tests. Table 6 reports estimates of (5). The production function seemed to have been properly identified. All but one of the elasticities of capital and labour were precisely estimated, of reasonable magnitude, and were not far from indicating constant returns to scale. The coefficient of the interaction between effective patent rights and patent intensity was positive and significant in the periods, 1981-85 and 1996-2000. Hence, we infer that, during these periods, stronger effective patent rights promoted growth through higher TFP growth (technical progress or better management) and possibly factor accumulation.

\section{[Insert Table 6 here]}

By Table 3, Panel A, industry growth of value added was positively associated with stronger effective patent rights in all periods. However, from Table 6, patent rights had no effect on total factor productivity growth during 1986-90 and 1991-95, so, during those periods, patent rights must have increased industry growth through factor accumulation. ${ }^{13}$

\section{Robustness checks}

We subjected our findings to multiple checks, focusing on sensitivity to the measures of effective patent rights and patent intensity. ${ }^{14}$

\subsection{Effective patent rights}

Our primary measure of effective patent rights represented the completeness of patent laws and their enforcement as the product of the GP and Fraser indexes. This measure was based

\footnotetext{
${ }^{13}$ The estimates in Table 6 were based on capital stock constructed with 5\% investment growth and $10 \%$ depreciation. In unreported estimates, we also estimated (5) with the capital stock constructed using other rates of investment growth and depreciation of capital, and obtained similar results.

${ }^{14}$ In other robustness checks, unreported for brevity, we sought to rule out effective patent rights being a proxy for other factors - financial development, openness to trade, and accumulation of human capital - that have been shown to influence economic growth. In each check, we included the interaction of the additional factor with patent intensity as an additional explanatory variable. Overall, our findings were robust to the inclusion of the possible confounds.
} 
on patent laws and enforcement being complements. So, to what extent were our findings robust to the measure of effective patent rights?

\section{[Insert Table 7 here]}

Table 7 reports estimates of the main specification, eq. (1), using alternative measures of effective patent rights. For brevity, we report only the coefficient of the interaction of effective patent rights with patent intensity. Table 7, Panel A, reports the estimates with the effective patent rights constructed as the geometric mean of the GP and Fraser indexes, as specified in (3). The results were similar to those with the main index of effective patent rights, but less precisely estimated. The coefficient of the interaction between patent rights and industry patent intensity was positive in all four periods and was statistically significant in 1991-95, and marginally significant in 1981-85 and 1996-2000. Consistent with the results applying the baseline index of effective patent rights index, patent rights had a larger effect in the 1990s as compared with the 1980s.

Likewise, with the additive measure of effective patent rights, constructed as the GP index plus half the Fraser index, as specified in (4), the results were similar to those with the main index of effective patent rights, but less precisely estimated. Further, with effective patent rights being simply measured by the Fraser index alone, the results were similar to those with the main index of effective patent rights. The results were weakest with effective patent rights being simply measured by the GP index alone, which further underscores the thinking that de jure law was of relatively little effect without enforcement.

Contrasting the results using the main index of effective patent rights (Table 3) with those from Fraser and GP indexes alone, it appeared that both law and enforcement contributed to industry growth. In particular, between 1986-1990, neither the Fraser index nor the GP index individually was significant, but the product of the Fraser and GP indexes (our primary measure of effective patent rights) was marginally significant.

Our identification strategy was premised on the assumption that country-industry idiosyncratic shocks were not correlated with national effective patent rights. To address 
potential violation of this assumption, we specified effective patent rights as at the beginning of each period, which would precede any industry specific shocks during the period. ${ }^{15}$

We further checked robustness using instrumental variables (IV), with effective patent rights instrumented by measures of legal origin that have been widely used as deep determinants of national institutions (La Porta et al. 2008). Kangur (2008) reviewed various indicators that have been proposed as instruments for differences in national institutions, and concluded that legal origin and IP rights were the most robust predictor. Legal origin might possibly directly affect industry growth, but this effect would be absorbed by the country fixed effects. Hence, the only remaining way by which legal origins could affect industry growth is through the interaction of effective patent rights with patent intensity, and so, this instrument would satisfy the exclusion condition.

Table 7, Panel E, reports the estimates of the first stage regression of the interaction of effective patent rights with patent intensity on initial value added and the interaction of legal origin with patent intensity, excluding Scandinavian legal origin. The null hypothesis that the instruments were valid was not rejected, and the $F$ statistic for weak instruments exceeded the Stock and Yogo (2005) critical values. The estimates suggested that effective patent rights were strongest in Scandinavian legal origin countries, then English legal origin countries, and weakest in French legal origin countries.

In the second stage, the IV-estimated coefficients of the interaction between effective patent rights and patent intensity were all positive, and mostly precisely estimated. The IV estimates were larger than the OLS estimates (Table 3). Considering the first-stage diagnostics and the second-stage estimates, we considered the IV estimates to be a strong check of robustness that suggested that the OLS estimates were reliable and actually conservative.

\footnotetext{
${ }^{15}$ In another robustness check, unreported for brevity, we organized the data as two 10-year countryindustry panels rather than four 5-year country-industry panels. The longer panels would further mitigate the effect of any pre-existing trend in effective patent rights. The results were similar, showing an increasing trend in the impact of national patent rights, but less precisely estimated than in the 5-year panels. We preferred the 5-year panels as they tracked the differences in effective patent rights more closely.
} 
Overall, we concluded that our findings were quite robust to the construction of the measure of effective patent rights.

\subsection{Patent intensity}

Our primary measure of industry patent intensity was the ratio of patents granted to sales among U.S. publicly listed companies reported in Compustat and the NBER Patent Database. In the next set of estimates, we checked the robustness of our findings to the measure of patent intensity.

\section{[Insert Table 8 here]}

Table 8 reports estimates of the main specification, eq. (1), using four alternative measures of patent intensity. Again, for brevity, we report only the coefficient of the interaction of patent rights with patent intensity and the corresponding estimated standard error. Table 8, Panel A, reports the estimates with patent intensity computed as the ratio of patent applications to sales by industry for the sample period of 1979-2000. The results were very close to the main estimates reported in Table 3. This is not surprising as patent grants are closely correlated with patent applications.

To the extent that proprietary knowledge, including that protected by patents, is an outcome of $R \& D$, the ratio of $R \& D$ to sales ( $R \& D$ intensity) provides an alternative measure of the importance of intellectual property to an industry. Accordingly, another robustness check used the R\&D intensity in place of patent intensity. As reported in Table 8, Panel B, the results were very close to the baseline specification. The coefficient of the interaction between patent rights and R\&D intensity was positive in all four periods and was statistically significant in 1981-85, 1991-95, and 1996-2000, and patent rights had a larger effect in the 1990s as compared with the 1980s.

Motivated by Rajan and Zingales (1998), our identification strategy depended in part on the U.S. patent intensities across industries differing from the patent intensities in other countries by at most an additive country-specific element. To guard against possible endogeneity, we excluded the United States from all estimates. 
Nevertheless, yet another way to check robustness would be to construct the benchmark for patent intensity using patent data from another jurisdiction. For a sharp contrast with the U.S. patent intensity, we turned to a developing country - China. We applied a similar method as that we used to compile the U.S. patent intensity. We counted patents granted by the State Intellectual Property Office of China and divided by the sales of the corresponding industry in China during the period.

Table 8, Panel C, reports the estimates of eq. (1) using the China patent intensity rather than the U.S. patent intensity. The industry coverage of the Chinese patent data was about half as large, so the power of the estimates was weaker. Nevertheless, the estimated coefficients of the interaction between effective patent rights and (Chinese) patent intensity were all positive, and precisely estimated in the period 1986-90 and marginally significant in the period 1996-2000. Given the much reduced sample size, we considered these estimates to be a reasonable robustness check.

Finally, we estimated eq. (1) with patent intensity replaced by Cohen et al.’s (2000) measure of the importance of patents for appropriating the returns to product innovation. As reported in Table 8, Panel $\mathrm{D}$, the results were more precise than our main estimates, and the effect of effective patent rights appeared to be stronger in the 1990s than the 1980s.

Overall, our results were quite robust to the construction of the benchmark of patent intensity. ${ }^{16}$

\section{Concluding Remarks}

We investigated whether stronger patent rights achieved their intended objective of stimulating economic growth. Despite its importance in the debate on the global

\footnotetext{
${ }^{16}$ We also explored instrumental variables estimation. Ciccone and Papaioannou $(2006,2010)$ proposed the only instrumental variables approach for cross-country cross-industry studies of which we are aware. Applied to our setting, their method generated many negative values for the world patent intensity. Moreover, in the second stage, the IV-estimated coefficients of the interaction between effective patent rights and patent intensity were significant but an order of magnitude larger than the OLS estimates. The negative estimates for the world patent intensity and the large discrepancy between the IV and OLS estimates gave rise to questions about the face validity of the IV estimates, and so, we did not report them.
} 
harmonization of IP protection, there has been little conclusive empirical evidence to support the claim that stronger patent rights indeed stimulate growth.

Using an unbalanced panel of up to 54 manufacturing industries in up to 72 countries between 1981-2000, we found evidence that stronger patent rights were associated with faster industrial growth measured by value added. The impact of the stronger effective patent rights was economically significant, and became stronger in the 1990s compared to the 1980s. Further, the impact was stronger in advanced economies than in developing economies. Stronger patent rights promoted industry growth through productivity increases and factor accumulation in the 1981-85 and 1996-2000 periods and through more rapid factor accumulation in the 1986-90 and 1991-95 periods.

Our results bear upon the public policy debate regarding the role of intellectual property rights in economic growth and development. We found that patent laws and their enforcement do matter for economic growth. However, we also found that stronger patent rights have less impact on economic growth in poorer economies and in less patent-intensive industries. Our findings lend empirical support to arguments that patent laws be tailored to the particular circumstances of country and industry (Burk and Lemley 2009).

In executing the empirical investigation, we had to deal with two challenging measurement issues. The GP index focuses on the completeness of patent laws but ignores the actual enforcement of such laws. We constructed an index of effective patent rights that combined both elements. However, in the absence of a measure of the enforcement of patent laws, we had to use an index of general law and property rights enforcement and assumed that this reflected the enforcement of patents. In future work, it would be good to refine the measure and so to more closely measure the economic impact of enforcement.

The other major issue was our application, in common with the various studies applying the Rajan and Zingales (1998) cross-industry, cross-country method, of U.S. patent intensities as a benchmark for all other countries, subject to an additive country-specific element. While we did check the robustness of the estimates, future work should do more to measure industry-level patent intensities in advanced and developing economies. Further, our measure of patent intensity simply counted the patents granted, with no adjustment for 
the quality or importance of the patents. Due attention to national differences in patent intensities, with adjustment for patent quality and importance, would provide the basis of more accurate estimates of the economic impact of patent rights.

\section{Acknowledgments}

We thank Bronwyn Hall, David Levine, Ashish Arora, Emeric Henry, Bernard Yeung, Matthew Henry, Minyuan Zhao, Josh Lerner, Elias Papaioannou, Stefan Wagner, Christian Helmers, the editor, and reviewers, and participants in seminars at the University of Connecticut, Goizueta Business School, HKUST, the $6^{\text {th }}$ IOMS Workshop, Tuck School, the Conference on Empirical Legal Studies, the Australian National University, and the Pacific Innovation Conference for helpful advice, and Kelvin Seah and Lim Zong Liang for able research assistance.

\section{Funding}

NUS Academic Research Fund (R-122-000-091-112 to AH and R-313-000-089-112 to IP). 


\section{References}

Aghion, P. and Howitt, P. (1998) Endogenous Growth Theory, MIT Press, Cambridge, MA.

Arora, A., Ceccagnoli, M., and Cohen, W. M. (2008) R\&D and the patent premium, International Journal of Industrial Organization, 26, 1153-79.

Barro, R. J. and Sala-i-Martin, X. (2004) Economic Growth (2nd edn) MIT Press, Cambridge, MA.

Becker, G. S. (1968) Crime and punishment: An economic approach, Journal of Political Economy, 76, 169-217.

Bessen, J. and Maskin, E. (2009) Sequential innovation, patents, and imitation, RAND Journal of Economics, 40, 611-35.

Branstetter, L., Fisman, R., and Foley, F. (2006) Do stronger intellectual property rights increase international technology transfer? Empirical evidence from U.S. firm-level data, Quarterly Journal of Economics, 121, 321-49.

Branstetter, L., Fisman, R., Foley, C. F., and Saggi, K. (2011) Does intellectual property rights reform spur industrial development? Journal of International Economics, 83, $27-$ 36.

Burk, D. L. and Lemley, M. A. (2009) The Patent Crisis and How the Courts Can Solve It, University of Chicago Press, Chicago, IL.

Chen, Q. (2008) The effect of patent laws on invention rates: Evidence from cross country panels, Journal of Comparative Economics, 36, 694-704.

Ciccone, A. and Papaioannou, E. (2006) Adjustment to Target Capital, Finance, and Growth, Discussion Paper No. 5969, Centre for Economic Policy Research.

Ciccone, A. and Papaioannou, E. (2010) Estimating cross-industry cross-country models using benchmark industry characteristics, Discussion Paper No. 8056, Centre for Economic Policy Research.

Cohen, W. M., Nelson, R. R., and Walsh, J. P. (2000) Protecting their intellectual assets: Appropriability conditions and why US manufacturing firms patent (or not), Working Paper No. 7552, NEBR.

Eaton, J. and Kortum, S. (1999) International technology diffusion: Theory and measurement, International Economic Review, 40, 537-70.

Ginarte, J. C. and Park, W. G. (1997) Determinants of patent rights: A cross-national study, Research Policy, 26, 283-301.

Green, J.R. and Scotchmer, S. (1995) On the division of profit in sequential innovation, Rand Journal of Economics, 26, 20-33. 
Gwartney, J., Lawson, R., and Samida, D. (2000) Economic Freedom of the World: 2000 Annual Report, Fraser Institute, Vancouver, BC.

Hall, B. H. (2007) Patents and patent policy, Oxford Review of Economic Policy, 23, 568-87.

Hall, B. H., Jaffe, A. B., and Trajtenberg, M. (2001) The NBER patent citations data file: Lessons, insights and methodological tools, Working Paper No. 8498, National Bureau of Economic Research, Cambridge, MA.

Hasan, I. and Tucci, C. L. (2010) The innovation-economic growth nexus: Global evidence, Research Policy, 39, 1264-76.

Hu, A. G.Z. and Jaffe, A. B. (2007) IPR, innovation, economic growth and development, Department of Economics, National University of Singapore.

Kangur, A. (2008) What rules in the 'deep' determinants of comparative development? Discussion Paper No. 386, Department of Economics, University of Oxford.

Kanwar, S. and Evenson, R. (2003) Does intellectual property protection spur technical change? Oxford Economic Papers, 55, 235-64.

Kanwar, S. (2012) The location of overseas research and development and intellectual property protection, Journal of Development Studies, 48, 1453-69.

Kim, Y. K., Lee, K., and Park, W. G. (2008) Appropriate intellectual property protection and economic growth in countries at different levels of development, 3rd Annual Conference of the EPIP Association, Bern, Switzerland.

La Porta, R., Lopez-de-Silanes, F., and Shleifer, A. (2008) The economic consequences of legal origins, Journal of Economic Literature, 46, 285-332.

Lederman, D. and Saenz, L. (2005) Innovation and development around the world, 19602000, Policy Research Working Paper No. 3774, World Bank.

Mookherjee, D. and Png, I. P. L. (1992) Marginal deterrence in enforcement of law, Journal of Political Economy, 102, 1039-66.

Moser, P. (2005) How do patent laws influence innovation? Evidence from nineteenthcentury world fairs, American Economic Review, 95, 1214-36.

Nicita, A. and Olarreaga, M. (2007) Trade, production and protection 1976-2004, World Bank Economic Review, 21, 165-71.

Nordhaus, W. D. (1969) Invention, Growth and Welfare: A Theoretical Treatment of Technological Change, MIT Press, Cambridge, MA.

Park, W. G. (2003) Do intellectual property rights stimulate R\&D and productivity growth? Evidence from cross-national and manufacturing industry data, in J. Putnam (ed.) 
Intellectual Property Rights and Innovation in the Knowledge-Based Economy, University of Calgary Press, Calgary.

Park, W. (2008) International patent protection: 1960-2005, Research Policy, 37, 761-6.

Park, W. and Ginarte, J. C. (1997) Intellectual property rights and economic growth, Contemporary Economic Policy, 15, 51-61.

Qian, Y. (2007) Do additional national patent laws stimulate domestic innovation in a global patenting environment: A cross-country analysis of pharmaceutical patent protection, 1978-2002, Review of Economics and Statistics, 89, 436-53.

Rajan, R. G. and Zingales, L. (1998) Financial dependence and growth, American Economic Review, 88, 559-86.

Scherer, F. M. (1972) Nordhaus' theory of optimal patent life: A geometric reinterpretation, American Economic Review, 62, 422-7.

Stock, J. and Yogo, M. (2005) Testing for weak instruments in linear IV regression, chapter 5, in D. W. K. Andrews (ed.) Identification and Inference for Econometric Models, Cambridge University Press, New York, 80-108.

Vichyanond, J. (2009) Intellectual property protection and patterns of trade, Department of Economics, Princeton University.

Yamada, T. (2005) Relevance and applicability of the UNIDO industrial statistics database for research purposes, UNIDO ESA/STAT/AC.105/21, Vienna.

Zeira, J. (2011) Innovations, patent races and endogenous growth, Journal of Economic Growth, 16, 135-56. 


\section{Appendix}

Table A Patent intensity

\begin{tabular}{llrr}
\hline $\begin{array}{l}\text { ISIC3 } \\
\text { (rev 3) }\end{array}$ & Industry & USPTO & $\begin{array}{r}\text { SIPO } \\
(\mathrm{x} 1000)\end{array}$ \\
\hline 15 & Food and beverages & 0.0012 & 0.1912 \\
16 & Tobacco & 0.0045 & 0.0046 \\
17 & Textiles & 0.0058 & 0.0229 \\
18 & Apparel & 0.0058 & 0.0027 \\
19 & Leather & 0.0105 & 0.0059 \\
20 & Wood products & 0.025 & 0.0254 \\
21 & Paper products & 0.0072 & 0.0143 \\
22 & Publishing, printing & 0.0063 & 0.0166 \\
23 & Coke and petroleum products & 0.0108 & 0.0111 \\
241 & Basic chemicals & 0.0272 & 0.5548 \\
242 & Other chemicals (incl. pharmaceuticals) & 0.024 & 1.7992 \\
25 & Rubber and plastics & 0.011 & 0.1233 \\
26 & Other non-metal & 0.0106 & 0.1971 \\
27 & Basic metals & 0.0107 & $0.0333^{\mathrm{a}}$ \\
28 & Fabricated metals & 0.0114 & 0.2331 \\
29 & Machinery and equipment & 0.0122 & 2.5302 \\
30 & Office, accounting, and computing machinery & 0.0513 & 0.0661 \\
311 & Electric motors, generators and transformers & 0.029 & \\
312 & Electricity distribution and control apparatus & 0.0463 & \\
313 & Insulated wire and cable & 0.0095 & $0.0727^{\mathrm{b}}$ \\
314 & Accumulators, primary cells and primary batteries & 0.142 & \\
315 & Electric lamps and lighting equipment & 0.0695 & \\
321 & Electronic valves, tubes and other electronic components & 0.0425 & $0.1091^{\mathrm{c}}$ \\
322 & TV and radio transmitters & 0.0423 & 0.0361 \\
323 & TV and radio receivers & 0.0163 & $0.1091^{\mathrm{c}}$ \\
331 & Medical appliances and instruments & 0.0323 & 2.2598 \\
34 & Motor vehicles, trailers and semi-trailers & 0.0105 & 0.0112 \\
35 & Other transport equipment & 0.0123 & $0.0084^{\mathrm{d}}$ \\
36 & Furniture and other manufactures & 0.013 & 0.3650 \\
\hline
\end{tabular}

Notes: Table presents patent intensities by 3-digit industry for industries with high patent intensity or of particular interest, else by 2-digit industry. USPTO patent intensity calculated as ratio of patents granted to deflated sales of companies covered by Compustat between 1979-2000. SIPO patent intensity calculated as number of all invention patents granted to all applicants divided by deflated sales of industry between 1998-2004, multiplied by 1000 .

a Average of ISIC 271 and 272

b SIPO data could concorded only for ISIC 31.

c SIPO patent intensity is only available for ISIC 322 and ISIC 32 less ISIC 322.

${ }^{\mathrm{d}}$ Excluding ISIC 352, whose patent intensity is 0.0333 . 
Figure 1. Fraser index vs. Ginarte-Park index

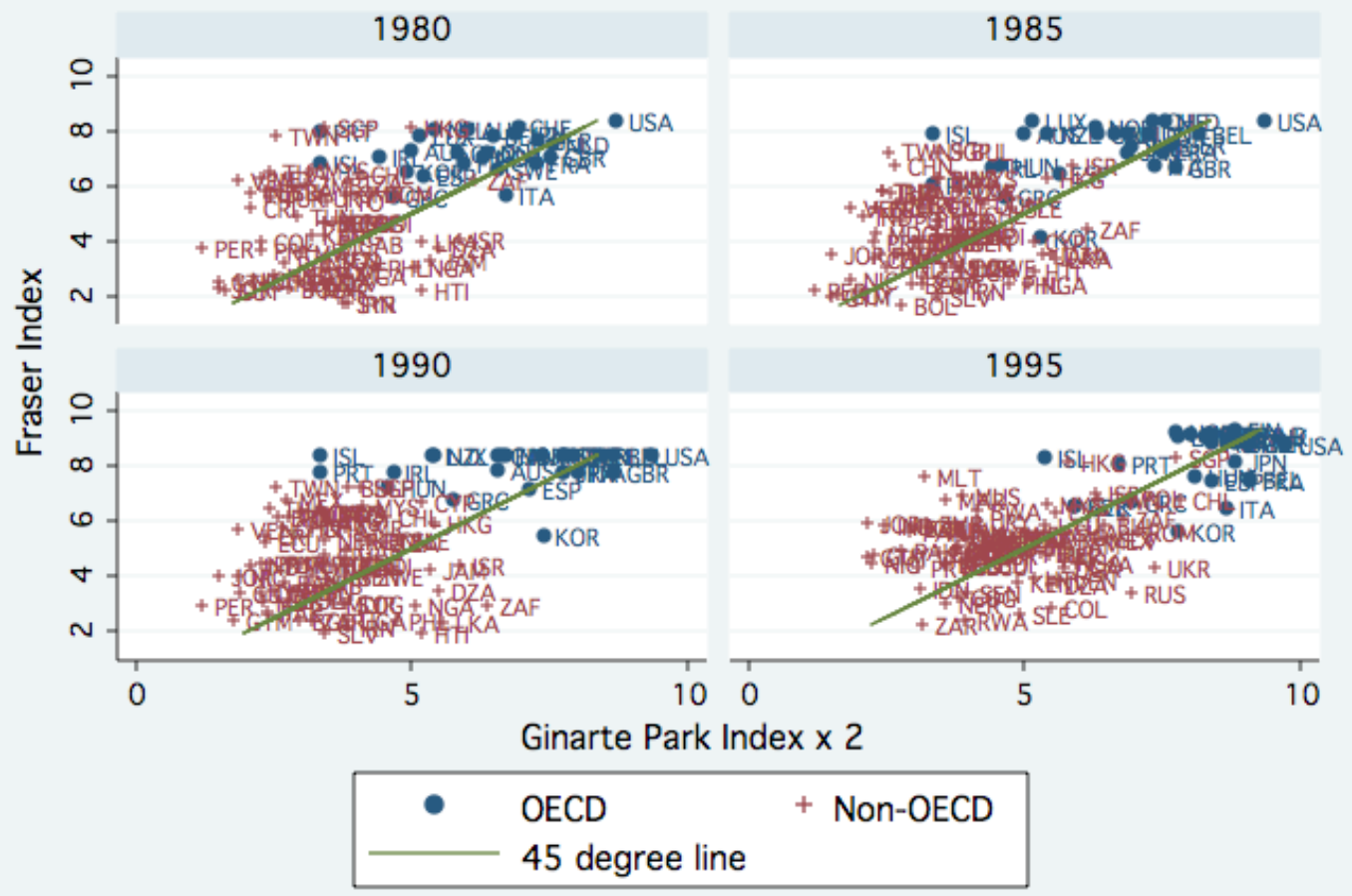

Graphs by year

Notes: The scale of the Fraser index was 0-10, while the scale of the GP index was 0-5. For easier visualization, the GP index was scaled up by a factor of 2 .

Figure 2. Effective patent rights index: Variance decomposition

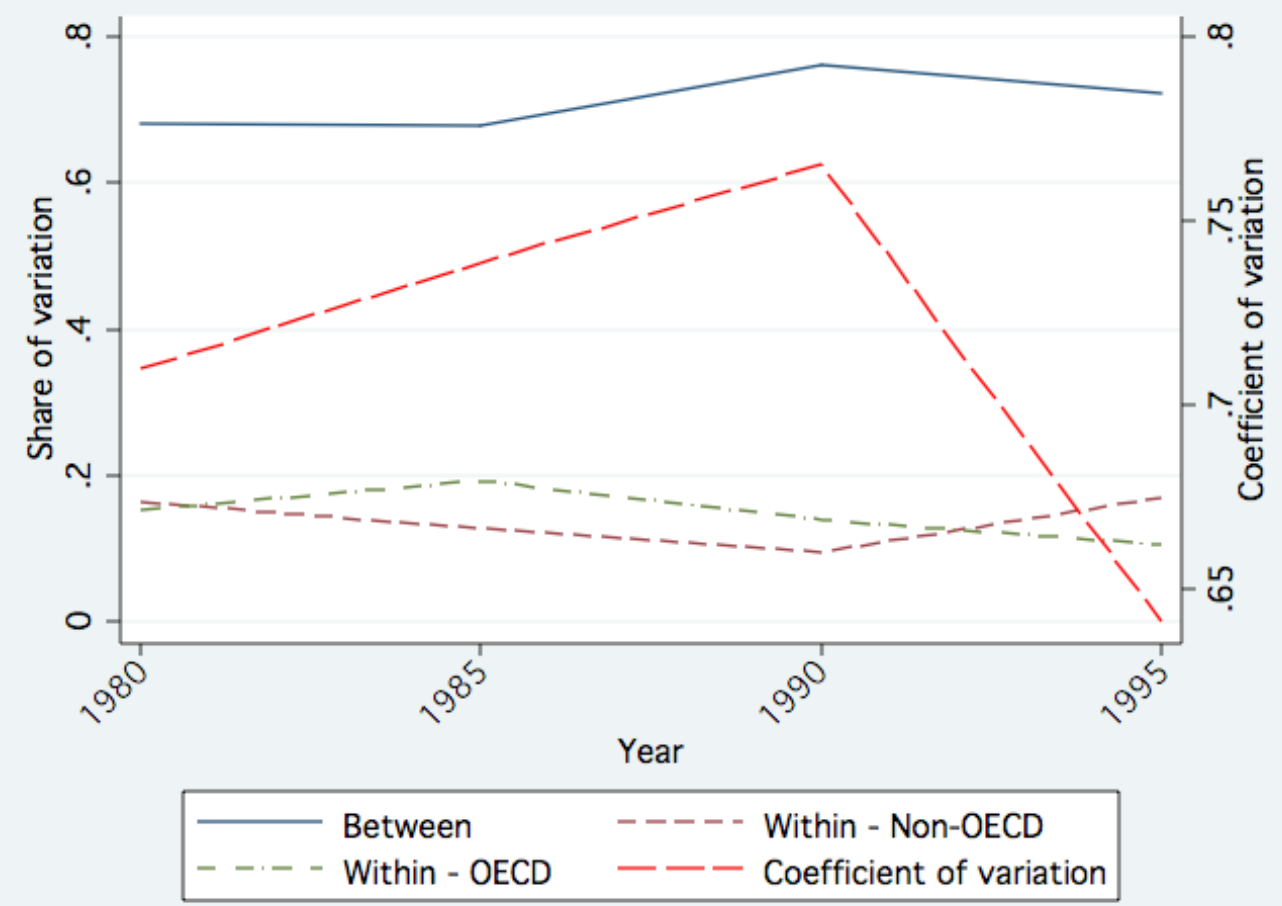

Notes: Coefficient of variation of the effective patent rights index (GP x Fraser) plotted against the right axis, and share of variation plotted against the left axis. 
Figure 3. Patent intensity and effective patent rights

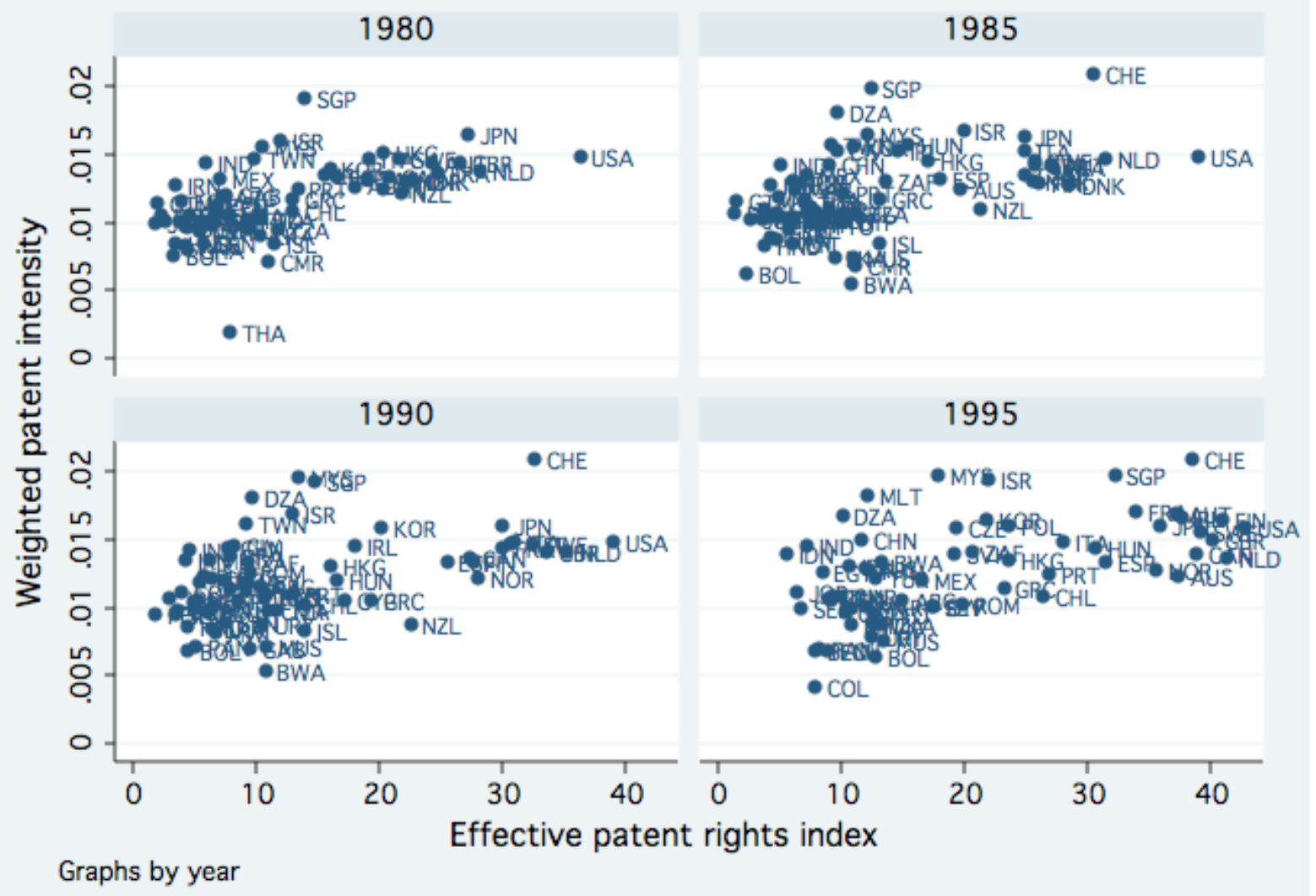

Notes: The vertical axis plots the weighted average patent intensity of a country, with the industry patent intensities weighted by the industries' shares of national value added, while the horizontal axis plots the effective patent rights index (GP x Fraser). 
Table 1. Effective patent rights index: Top and bottom countries

1980

\begin{tabular}{cc}
\multicolumn{2}{c}{1980} \\
\\
U.S.A. & 39.30 \\
Netherlands & 28.20 \\
Japan & 27.14 \\
U.K. & 26.49 \\
France & 24.79 \\
& \\
Bolivia & 3.21 \\
Pakistan & 2.67 \\
Peru & 2.22 \\
Guatemala & 1.90 \\
Jordan & 1.72
\end{tabular}

58
Top five countries
1985

1990

1995

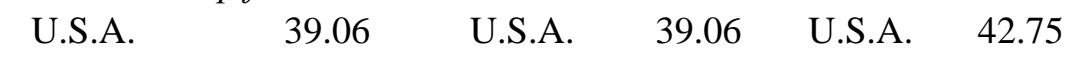

Netherlands $\quad 31.47 \quad$ Netherlands 35.22 Netherlands 41.36

$\begin{array}{llllll}\text { Switzerland } & 30.55 & \text { U.K. } & 33.57 & \text { Finland } 41.01\end{array}$

$\begin{array}{lllll}\text { Denmark } \quad 28.60 & \text { Switzerland. } & 32.63 & \text { U.K. } & 40.15\end{array}$

France $\quad 27.25 \quad$ Sweden $32.38 \quad$ Sweden 39.13

Bottom five countries

$\begin{array}{cccccc}\text { Bangladesh } & 3.62 & \text { Colombia } & 3.86 & \text { Colombia } & 7.80 \\ \text { Jordan } & 2.61 & \text { Bangladesh } & 3.59 & \text { India } & 7.22 \\ \text { Bolivia } & 2.30 & \text { El Salvador } & 3.34 & \text { Senegal } & 6.73 \\ \text { Guatemala } & 1.50 & \text { Jordan } & 2.95 & \text { Jordan } & 6.43 \\ \text { Peru } & 1.31 & \text { Peru } & 1.73 & \text { Indonesia } & 5.53\end{array}$

Number of countries (excluding U.S.A.) 66
67
61

Note: We excluded the U.S.A. from all our regressions, but present the U.S. index as a reference for the values for the other countries. 
Table 2. Descriptive statistics

\begin{tabular}{|c|c|c|c|c|c|c|c|}
\hline $\begin{array}{c}\text { VA } \\
\text { growth }\end{array}$ & $\begin{array}{l}\text { Fraser } \\
\text { Index }\end{array}$ & $\begin{array}{l}\text { GP } \\
\text { index }\end{array}$ & $\begin{array}{l}\text { Effective } \\
\text { patent rights } \\
\text { index }\end{array}$ & $\begin{array}{c}\text { Patent } \\
\text { intensity }\end{array}$ & $\begin{array}{l}\text { R\&D/ } \\
\text { Sales }\end{array}$ & $\begin{array}{c}\text { Capital } \\
\text { (\$ mill.) }\end{array}$ & Labor \\
\hline \multicolumn{8}{|l|}{ 1981-85 } \\
\hline-0.005 & 5.35 & 2.07 & 11.853 & 0.018 & 0.023 & 781 & 18,229 \\
\hline$(0.153)$ & (1.923) & $(0.833)$ & (7.490) & $(0.022)$ & (0.023) & $(8,551)$ & $(43,172)$ \\
\hline 2962 & 2962 & 2962 & 2962 & 2962 & 2962 & 1,688 & 2,918 \\
\hline \multicolumn{8}{|l|}{$1986-90$} \\
\hline 0.126 & 5.475 & 2.061 & 12.322 & 0.018 & 0.023 & 588 & 30,195 \\
\hline$(0.197)$ & $(1.827)$ & (0.909) & (8.412) & $(0.022)$ & (0.023) & $(2,032)$ & $(108,727)$ \\
\hline 3185 & 3185 & 3185 & 3185 & 3185 & 3185 & 1,844 & 3,157 \\
\hline \multicolumn{8}{|l|}{$1991-95$} \\
\hline 0.036 & 5.624 & 2.176 & 13.218 & 0.018 & 0.023 & 954 & 34,845 \\
\hline$(0.224)$ & (1.921) & $(0.984)$ & $(9.400)$ & $(0.022)$ & (0.023) & $(2,823)$ & $(152,166)$ \\
\hline 3244 & 3244 & 3244 & 3244 & 3244 & 3244 & 1,691 & 3,232 \\
\hline \multicolumn{8}{|l|}{$1996-2000$} \\
\hline-0.007 & 6.349 & 2.952 & 19.854 & 0.018 & 0.023 & 1,564 & 40,664 \\
\hline$(0.224)$ & (1.672) & (1.034) & (11.177) & $(0.022)$ & (0.023) & $(4,348)$ & $(168,115)$ \\
\hline 2837 & 2837 & 2837 & 2837 & 2837 & 2837 & 1,396 & 2,781 \\
\hline
\end{tabular}

Notes: Each panel reports mean (first row), standard deviation (second row), and number of observations (third row).

Table 3. Main estimates
(1)
(2)
(3)
(4)

VARIABLES $\quad$ 1981-1985 1986-1990 1991-19951996-2000

\begin{tabular}{lcccc}
\hline A. All data & \multicolumn{4}{c}{} \\
Initial value added & $-0.0154^{* * *}-0.0496^{* * *}-0.0382^{* * *}$ & $-0.0117^{*}$ \\
& $(0.00427)$ & $(0.00619)$ & $(0.00906)$ & $(0.00599)$ \\
Effective patent rights & $0.0129^{*}$ & $0.0128^{*}$ & $0.0442^{* * *}$ & $0.0191^{* *}$ \\
$\quad$ x patent intensity & $(0.00707)$ & $(0.00708)$ & $(0.0101)$ & $(0.00941)$ \\
Country fixed effects & Yes & Yes & Yes & Yes \\
Year fixed effects & Yes & Yes & Yes & Yes \\
Observations & 2962 & 3185 & 3244 & 2837 \\
R-squared & 0.549 & 0.577 & 0.464 & 0.459 \\
B. Balanced panel & & & & \\
Initial value added & -0.00354 & $-0.0582^{* * *}$ & $-0.0254^{*}$ & 0.00699 \\
& $(0.00467)$ & $(0.00626)$ & $(0.0133)$ & $(0.00760)$ \\
Rights x patent intensity & 0.00493 & $0.0146 *$ & $0.0199 * *$ & $0.0348 * * *$ \\
& $(0.00773)$ & $(0.00795)$ & $(0.00829)$ & $(0.0110)$ \\
Country fixed effects & Yes & Yes & Yes & Yes \\
Year fixed effects & Yes & Yes & Yes & Yes \\
Observations & 1795 & 1795 & 1795 & 1795 \\
R-squared & 0.701 & 0.714 & 0.544 & 0.525
\end{tabular}

Notes. Dependent variable: Average growth of ln industry value added over 5-year period. Effective patent rights specified as product of GP index and Fraser index; patent intensity computed as ratio of patent grants to sales. Robust standard errors in parentheses $\left({ }^{* * *} \mathrm{p}<0.01,{ }^{* *} \mathrm{p}<0.05\right.$, $\left.{ }^{*} \mathrm{p}<0.1\right)$. 
Table 4. Counterfactuals

\begin{tabular}{lccccc} 
& Patent & $(1)$ & $(2)$ & $(3)$ & $(4)$ \\
INDUSTRY & intensity & $1981-1985$ & $1986-1990$ & $1991-1995$ & $1996-2000$ \\
\hline ISIC 19 & 0.0105 & 0.0011 & 0.0014 & 0.0047 & 0.0025 \\
$\quad$ (Leather) & & $(0.0006)$ & $(0.0006)$ & $(0.0010)$ & $(0.0011)$ \\
ISIC 20 & 0.0250 & 0.0027 & 0.0034 & 0.0111 & 0.0060 \\
$\quad$ (Wood products) & & $(0.0013)$ & $(0.0015)$ & $(0.0024)$ & $(0.0026)$ \\
ISIC 242 & 0.0240 & 0.0026 & 0.0033 & 0.0107 & 0.0057 \\
$\quad$ (Other chemicals) & & $(0.0013)$ & $(0.0015)$ & $(0.0023)$ & $(0.0025)$ \\
ISIC 30 (Office, accounting & 0.0513 & 0.0056 & 0.0070 & 0.0228 & 0.0122 \\
$\quad$ \& computing machinery) & & $(0.0027)$ & $(0.0031)$ & $(0.0050)$ & $(0.0054)$
\end{tabular}

Notes: Each panel presents, for the industry and 5-year period: change in the average growth of ln industry value added associated with one standard deviation increase in effective patent rights, standard error (in parentheses). Counterfactual calculations are based on estimated coefficients from Table 3, Panel A.

\section{Table 5. Income contingency}
(1)
(2)

(3)

(4)

VARIABLES

1981-1985 1986-1990 1991-1995 1996-2000

\begin{tabular}{|c|c|c|c|c|}
\hline Initial value added & $\begin{array}{c}-0.0154 * * * \\
(0.00427)\end{array}$ & $\begin{array}{l}-0.0497 * * * \\
(0.00619)\end{array}$ & $\begin{aligned}-0.0383^{* * *} \\
(0.00906)\end{aligned}$ & $\begin{array}{l}-0.0117^{*} \\
(0.00600)\end{array}$ \\
\hline $\begin{array}{l}\text { Effective patent rights x patent intensity } \\
\text { x GDP per capita }\end{array}$ & $\begin{array}{l}0.00137 * * \\
(0.000691)\end{array}$ & $\begin{array}{l}0.00157 * * \\
(0.000723)\end{array}$ & $\begin{array}{l}0.00419 * * * \\
(0.000982)\end{array}$ & $\begin{array}{l}0.00181 * * \\
(0.000851)\end{array}$ \\
\hline Country fixed effects & Yes & Yes & Yes & Yes \\
\hline Year fixed effects & Yes & Yes & Yes & Yes \\
\hline Observations & 2962 & 3185 & 3244 & 2837 \\
\hline R-squared & 0.549 & 0.577 & 0.464 & 0.459 \\
\hline
\end{tabular}

Notes. Dependent variable: Average growth of ln industry value added over 5-year period. Effective patent rights specified as product of GP index and Fraser index; patent intensity computed as ratio of patent grants to sales. Robust standard errors in parentheses $\left({ }^{* * *} \mathrm{p}<0.01,{ }^{* *} \mathrm{p}<0.05,{ }^{*} \mathrm{p}<0.1\right)$. 
Table 6. Productivity growth

(1) (2) (3)

(4)

VARIABLES 1981-19851986-19901991-19951996-2000

\begin{tabular}{lcccc}
\hline Change in & 0.0553 & $0.182^{* * *}$ & $0.255^{* * *}$ & $0.291^{* * *}$ \\
$\quad$ log of capital services & $(0.0523)$ & $(0.0567)$ & $(0.0627)$ & $(0.0813)$ \\
Change in & $0.888^{* * *}$ & $0.788^{* * *}$ & $0.626^{* * *}$ & $0.892^{* * *}$ \\
$\quad$ log of labor & $(0.0541)$ & $(0.103)$ & $(0.0713)$ & $(0.0631)$ \\
Effective patent rights & $0.0120^{* *}$ & -0.00695 & 0.00423 & $0.0442 * *$ \\
x patent intensity & $(0.00525)$ & $(0.00607)$ & $(0.00588)$ & $(0.0181)$ \\
Country fixed effects & Yes & Yes & Yes & Yes \\
Year fixed effects & Yes & Yes & Yes & Yes \\
Observations & 1598 & 1856 & 1638 & 1419 \\
R-squared & 0.828 & 0.652 & 0.599 & 0.780
\end{tabular}

Notes. Estimate of equation (5). Dependent variable: Average growth of ln industry value added over 5 -year period. Depreciation rate, $\delta=0.1$, growth rate of investment, $\gamma=0.05$. Effective patent rights specified as product of GP index and Fraser index; patent intensity computed as ratio of patent grants to sales. Robust standard errors in parentheses $\left({ }^{* * *} \mathrm{p}<0.01,{ }^{* *} \mathrm{p}<0.05,{ }^{*} \mathrm{p}<0.1\right)$.

\section{Table 7. Effective patent rights}

VARIABLES (1) (2) (3) (4)

\begin{tabular}{|c|c|c|c|c|}
\hline $\begin{array}{l}\text { A. Geometric mean: } \\
(\text { Fraser x GP })^{1 / 2}\end{array}$ & $\begin{array}{l}0.0967 * \\
(0.0500)\end{array}$ & $\begin{array}{c}0.0754 \\
(0.0514)\end{array}$ & $\begin{array}{l}0.371 * * * \\
(0.0798)\end{array}$ & $\begin{array}{c}0.163^{*} \\
(0.0901)\end{array}$ \\
\hline B. Average: (GP + & $0.0757 * *$ & 0.0614 & $0.284 * * *$ & $0.123^{\prime}$ \\
\hline 0.5 x Fraser) & $(0.0373)$ & $(0.0374)$ & $(0.0601)$ & $(0.0675)$ \\
\hline C. Fraser index & $\begin{array}{l}0.0776 * * \\
(0.0342)\end{array}$ & $\begin{array}{c}0.0545 \\
(0.0359)\end{array}$ & $\begin{array}{c}0.261 * * * \\
(0.0636)\end{array}$ & $\begin{array}{l}0.186^{* *} \\
(0.0920)\end{array}$ \\
\hline D. GP index & $\begin{array}{c}0.0530 \\
(0.0630)\end{array}$ & $\begin{array}{c}0.0908 \\
(0.0683)\end{array}$ & $\begin{array}{l}0.347 * * * \\
(0.0834)\end{array}$ & $\begin{array}{c}0.0885 \\
(0.0818)\end{array}$ \\
\hline \multicolumn{5}{|l|}{ E. Instrumental variables } \\
\hline $\begin{array}{c}\text { British legal origin } \\
\text { x patent intensity }\end{array}$ & $\begin{array}{c}-7.567 * * * \\
(1.537)\end{array}$ & $\begin{array}{c}-11.38 * * * \\
(1.850)\end{array}$ & $\begin{array}{c}-12.59 * * * \\
\\
(2.526)\end{array}$ & $\begin{array}{c}-8.646 * * * \\
(3.243)\end{array}$ \\
\hline $\begin{array}{l}\text { French legal origin } \\
\text { x patent intensity }\end{array}$ & $\begin{array}{c}-10.89 * * * \\
(1.482)\end{array}$ & $\begin{array}{c}-15.02 * * * \\
(1.822)\end{array}$ & $\begin{aligned}- & 15.61 * * * \\
& (2.470)\end{aligned}$ & $\begin{array}{c}-15.80 * * * \\
(2.887)\end{array}$ \\
\hline $\begin{array}{l}\text { German legal origin } \\
\text { x patent intensity }\end{array}$ & $\begin{array}{l}2.397 \\
(2.089)\end{array}$ & $\begin{array}{l}-1.183 \\
(2.807)\end{array}$ & $\begin{array}{l}2.190 \\
(2.725)\end{array}$ & \\
\hline Kleibergen-Paap rk Wald $F$ statistic & 28.03 & 28.57 & 39.81 & 102.65 \\
\hline Second stage & $\begin{array}{l}0.0178^{*} \\
(0.0107)\end{array}$ & $\begin{array}{l}0.0211^{* *} \\
(0.00903)\end{array}$ & $\begin{array}{l}0.0601^{* * *} \\
(0.0157)\end{array}$ & $\begin{array}{c}0.0235 \\
(0.0151)\end{array}$ \\
\hline
\end{tabular}

Notes: Each panel reports the coefficient of the interaction of patent rights with patent intensity in a regression of the growth of In industry value added on initial value added and patent rights $\mathrm{x}$ patent intensity with country and industry fixed effects over the 5-year period. Patent intensity computed as ratio of patent grants to sales. Panels differed in construction of the index of effective patent rights: A. Geometric mean: (Fraser x GP) 1/2; B. Average: (GP + 0.5 x Fraser); C. Fraser index; D. GP index; E. Effective patent rights computed as Fraser x GP, and instrumented by legal origin (La Porta et al. 2008); first stage reports coefficients of legal origin $x$ patent intensity in regression of effective patent rights $\mathrm{x}$ patent intensity on initial value added and legal origin $\mathrm{x}$ patent intensity, and second stage reports coefficient of interaction of patent rights with patent intensity in regression of growth of ln industry value added on patent rights $x$ patent intensity and controls. Robust standard errors in parentheses $\left({ }^{* * *} \mathrm{p}<0.01,{ }^{* *} \mathrm{p}<0.05,{ }^{*} \mathrm{p}<0.1\right)$. 
Table 8. Patent intensity

(1) (2) (3) (4)

VARIABLES

1981-19851986-19901991-19951996-2000

\begin{tabular}{lccccc}
\hline A. Patent applications & $0.0153^{*}$ & 0.0131 & $0.0605^{* * *}$ & $0.0216^{* *}$ \\
- sales ratio & $(0.00815)$ & $(0.00870)$ & $(0.0119)$ & $(0.0104)$ \\
B. R\&D-sales ratio & $0.0172^{* *}$ & 0.0115 & $0.0638^{* * *}$ & $0.0210^{* *}$ \\
& $(0.00860)$ & $(0.0102)$ & $(0.0125)$ & $(0.00991)$ \\
C. China patent intensity & 0.359 & $0.737^{* *}$ & 0.551 & $0.894^{*}$ \\
& $(0.304)$ & $(0.327)$ & $(0.397)$ & $(0.504)$ \\
D. Patent importance & $0.0617^{* *}$ & $0.0634^{* *}$ & $0.119 * * *$ & $0.129 * * *$ \\
$\quad$ (Cohen et al. 2000) (x1000) & $(0.0248)$ & $(0.0305)$ & $(0.0324)$ & $(0.0327)$
\end{tabular}

Notes: Each panel reports the coefficient of the interaction of patent rights with patent intensity in a regression of the growth of $\ln$ industry value added on initial value added and patent rights $\mathrm{x}$ patent intensity with country and industry fixed effects over the 5-year period. Effective patent rights were specified as the product of GP index and Fraser index. Panels differed in construction of patent intensity: A. Ratio of patent applications to sales; B. Ratio of R\&D to sales; C. Ratio of patent grants to sales in China. D. Importance of patents in product innovation (Cohen et al. 2000). Robust standard errors in parentheses $\left({ }^{* * *} \mathrm{p}<0.01,{ }^{* *} \mathrm{p}<0.05\right.$, $\left.{ }^{*} \mathrm{p}<0.1\right)$. 